Јасмина Московљевић Поповић

Универзитет у Београду

Филолошки факултет

e-mail: jasmina.moskovljevic@fil.bg.ac.rs

https://doi.org/10.18485/ai_san_o_gradu.2020.ch13

$81^{\prime} 42$

Оригинални научни рад

\title{
ДИСКУРСНА РЕПРЕЗЕНТАЦИЈА УРБАНИХ ПРОСТОРА У ТЕКСТУ ПРИПОВЕТКЕ ДАН У РИМУ
}

У раду се анализирају различити типови дискурса којима Андрић репрезентује урбани простор и његове сегменте у тексту приповетке Дан у Рuмy. Резултати анализе показују да се наратизована дескрипција јавља као доминантан облик спацијалне карактеризације. Као алтернативни облици дискурсне репрезентације простора уочавају се дескрипција и директна референција (именовање спацијалних ентитета). Одсуство дискурсне репрезентације појединих простора, или њена реализација у изузетно сведеном облику, представљају још један од уочених облика Андрићевог репрезентовања спацијалности.

Кључне речи: урбани простори, типови дискурса, наратизована дескрипција, директна референција, дескрипција, одсуство дискурсне репрезентације; Андрић, приповетка.

1. Место и простор су дуго, све до друге половине двадесетог века, били предмет интересовања махом у природним наукама, док су у лингвистици и књижевној теорији заузимали место споредних, пратећих елемената комуникативног чина, било да је реч о дискурсу свакодневне комуникације или о књижевном ствара- 
лаштву. Тек у другој половини 20. века проблем простора актуализован је како у оквиру лингвистичких, тако и књижевнотеоријских проучавања. У когнитивној лингвистици формулисана је хипотеза о простору као основној, аксиоматској категорији и просторним релацијама као релацијама које леже у основи свих језичких репрезентација, док се саме репрезентације одређују као метафоричне или метонимијске транспозиције просторних релација (Lakoff \& Johnson 1980; Langacker 1987). Готово истовремено, у књижевној теорији отворен је читав низ питања везаних за наративни и, уопште, текстовни простор, за међуоднос простора и времена у тексту, као и за различите модусе језичке, дводимензионалне и линеарно-темпоралне репрезентације тродимензионалног физичког окружења (Bakhtin 1986, Zoran 1984). Уз ова, као уско повезана, али ипак посебна питања издвајају се она која се односе на типичне, чешће заступљене, и мање типичне језичке облике и типове дискурса који се јављају при карактеризацији простора у текстовима различитих жанрова и књижевно-историјских епоха (Herman 2009; Ryan 2014).

Како питање језичке и дискурсне репрезентације простора и просторних релација на текстовној грађи из Андрићевих приповедака досад није посебно разматрано иако оне пружају разноврсан и богат материјал за сваковрсна истраживања спацијалних релација у универзуму наратива, ${ }^{1}$ основни циљ овог прилога је да се изврши прелиминарна анализа грађе ограниченог обима и изложе њени иницијални резултати. Зато је даље разматрање усмерено на текст само једне од приповедака сабраних у збирци Приче о градовима (Андрић 2017) - текст приповетке Дан у Рuмy.

1 Терминолошка синтагма наративни простор, као и сви други термини који се у овом раду користе, употребљавају се у значењу дефинисаном у Ryan (2014). 
2. Иако је реч о једној од првих Андрићевих приповедака (написана је 1920. године), у њеном тексту могуће је јасно издвојити неколико различитих типова и подтипова дискурсне репрезентације урбаног простора, у овом случају - Рима, и његових ширих и ужих целина, пејзажа и ентеријера.

2.1. Као најдоминантнији и најприсутнији тип дискурса којим се у овој приповеци карактерише простор издваја се дискурс наратизоване дескрипиије. Наратизована дескрипција дефинише се као тип дискурса чија формална својства одговарају наративном типу текста, али чија примарна функција није наративна, већ дескриптивна (Mosher 1991: 426-427). Дискурс наратизоване дескрипције широко је заступљен у тексту приповетке Дан у Риму. Њиме Андрић репрезентује град као целину (1), али и његове поједине делове $(2,4)$, као и његове унутрашње просторе, ентеријере (3):

(1) Брзо је сишао низ бријег. Доље у граду већ се смркава. Врева и безбројан свијет. Улице се дуље и савијају. Сваки угао обећава да ће се нешто пријатно догодити. Вече мирише на авантуру. Свирка издалека („Као у Одеси“) (14).

(2) ... кад се успео на Пинчио. Парк пун свијета. Трешти војна музика. Како се лако иде, испаван и умивен, по стазама још влажна пијеска за које се не зна куда воде! Сунце залази поред куполе Светог Петра. [...] На тераси, наслоњени на камену балустраду, људи што посматрају Рим и сунце које залази. Талијани. Енглези са фотографским апаратима. Неки брадат јерменски епископ, са пратњом. Парови који се чврсто држе за руке (13-14).

(3) Уђоше полако у цркву, из које је допирао крупан глас. У пространој цркви, у свјетлу кишна дана, бјеше мало свијета; са амвона је грмио плећат 
и обријан презбитеријански пастор. [...] Пастор ућута, а један висок човјек с брадом и наочарима сједе за хармонијум и поче да пјева у басу, пратећи се сам. Жене из клупа прихватише (12).

(4) Мала пјацета испуњена тамом и шумом вјетра и воде. Југова ноћ без звијезда. Насред трга фонтана баца високо воду, а вјетар јој заноси млаз преко базена и просипа с пљуском по калдрми (19).

У сва четири одломка већина реченичних предиката формирана је са акционим глаголима ( $y \hbar u, u \hbar u, ~ г p-$ мети, певати, прихватити, обећавати, просипати...) реализованим у облику актива. Слике простора које овакве реченичне конструкције побуђују нису статичне и непроменљиве, већ живе и покретне, у сталном флуксу и промени. Град и његови простори не репрезентују се као пука позадина, мртва сцена, кулисе за догађања. Дискурс којим се о њима говори зато и не може да буде дискурс канонске дескрипције. Напротив, град се примарно репрезентује управо преко оног шта се у њему догађа, он се у свету наратива појављује и приказује као својеврсно огледало, рефлексија живота и кретања које се у њему одвија. Чак и иначе статични објекти (фонтана на пјацети) добијају динамичку репрезентацију (фонтана воду баца високо, ветар заноси млаз воде и просипа га с пљуском). Мимо овог хоризонта, хоризонта акције и догађања, у тексту одломака мало тога се може наћи о реалним физичким и топографским обележјима урбаних простора Рима и његових делова. О њима се сазнаје успут, преко спорадичне употребе прилошких лексема и синтагми спацијалног значења (доље у граду, на Пинчио, на тераси, поред куполе Светог Петра), на основу којих једва да је могуће (ако је уопште могуће) реконструисати само фрагментарну, непотпуну мапу града. 
2.2. У готово занемарљивом обиму у односу на заступљеност дискурса наратизоване дескрипције, у тексту приповетке Дан у Риму заступљен је и дискурс (канонске, праве) дескрипиије. Андрић му у овом тексту прибегава само једном, приликом репрезентације ентеријера неименованог римског ресторана који постаје главно поприште догађања у причи: Мален ресторан. У юему густо поредани столови, малени и бијели. Већ ретки гости. Пријатно свјетло (14).

Пар кратких реченица елиптичне синтаксичке структуре, без глагола у финитном глаголском облику, конституишу дескриптивни пасаж којим се репрезентује просторни оквир (енг. spatial frame), ${ }^{2}$ позорница на којој ће уследити догађаји на основу којих главни јунак приче, потпоручник Крлетић, формира свој укупни суд о Риму („Све сам голи хајдук!'). И то је једини део текста ове приповетке у коме је неки урбани простор репрезентован као тих, миран и статичан.

2.3. Као следећи облик текстуализације простора у приповеци Дан у Риму могуће је издвојити делове текста који директно, именовањем, упућују на стварне, реално постојеће локалитете. Таква је, на пример, употреба топонима PuM, Via Nacionale и Пинчио. Први се јавља већ у самом наслову, као и на још пар места у тексту и детерминише, у терминима Мари Лор Рајан, шире физичко окружене (енг. setting) ${ }^{3}$ у коме се радња приповести одвија. Други и трећи су ту да би упутили на одређене, јасно издвојене спацијалне оквире који су поприште дешавања појединих наративних епизода.

Уз означавање места и простора у којима се протагонисти наратива физички налазе и крећу, топоними

2 Ryan 2014.

3 Ryan, ibid. 
се у тексту јављају и као означитељи и међаши унутар простора сећања главног јунака. Тако Мостар, Сарајево, Херцеговина, Лондон и Париз постоју референтни спацијални оквири унутар универзума наратива, ${ }^{4}$ простори стицања свеукупног дотадашњег животног искуства потпоручника Крлетића на основу кога он препознаје, самерава и вреднује и Рим и све оно што у њему види и што му се дешава.

2.4. На крају, у тексту приповетке повремено се упућује и на сегменте простора о чијим локализацијским, картографским, као ни појавним, физичким карактеристикама читалац не сазнаје ништа, или готово ништа. Њихову спацијалну репрезентацију одликује недостатак карактеризације, празнина, одсуство дискурса који би се њима бавио. Такав је случај са текстовном репрезентацијом хотела у коме потпоручник Крлетић одседа у Риму: Стигао је једне вечери у марту, и пошто је предао пуковнику пошту, одвео га је Станић у хотел (11)“. И то је све што о простору хотела читалац сазнаје. Ни његову локацију, ни димензије, ни било шта о његовом изгледу, окружењу и уређењу. Наравно, ово није нимало случајно - хотел је за потпоручника Крлетића само нужна успутна станица његовог и иначе успутног боравка у Риму. Да је тако сведочи и наставак текста: Пошто је извадио иивилно одијело из кофера и метнуо панталоне испод душека, да би сутра имале форму, и пошто је ћемер са уштеђеним наполеонима метнуо под јастук, Крлетић леже и заспа одмах (12). Хотел је само неопходно склониште, неспецификовани тродимензионални простор, место предаха и задовољавања примарне физиолошке потребе за сном. Отуда било које друго његово својство није важно, ни битно,

4 Ibid. 
па нема ни његове текстовне репрезентације. Одсуство дискурса о неком ентитету постаје тако стилски изразито ефектан индикатор функције и значаја тог ентитета у хијерархизованом свету актуалног наратива.

3. Иако је у тексту овог прилога анализа облика дискурсне репрезентације простора у Андрићевој приповедној прози извршена на грађи врло скромног обима, већ и њени иницијални резултати показују да су модуси репрезентације простора у Андрићевом тексту многолики и, кад је о типолошкој структури дискурса реч, врло разноврсни. Као доминантан начин репрезентације урбаног простора у текстовној структури приповетке Дан y Риму издваја се дискурс наратизоване дескрипције, али су присутни и други типови дискурса - дескриптивни (посебно при репрезентовању ентеријера), као и дискурс именовања (односно директног означавања и картографског упућивања на одређени спацијални ентитет). Као посебан облик дискурсне (не)репрезентације може се пратити и оса, хоризонт нереализованог дискурса, чија је функција у структури текста врло специфична и детерминисана позицијом одређеног ентитета у хијерархизованој просторној мрежи наратива.

\section{Извор и литература}

Andrić, Ivo. Priče o gradovima. Beograd: Laguna, 2017.

Bakhtin, Mikhail Mikhailovich. Speech Genres and Other Late Essays. Prevod: Vern W. McGee. Austin: University of Texas Press, 1986.

Herman, David. Basic Elements of Narrative. Oxford: WileyBlackwell, 2009.

Langacker, Ronald W. Foundations of Cognitive Grammar: Theoretical prerequisites, Volume 1. Stanford, CA: Stanford University Press, 1987. 
Lakoff, George \& Johnson, Mark. Metaphors We Live By. Chicago,

IL: Chicago University Press, 1980.

Mosher, Harold F., Jr. „Toward a Poetics of 'Descriptized'

Narration". Poetics Today, Vol. 12/3, (1991): 425-445.

Ryan, Marie-Laure. „Space”. U: Hühn, Peter et al. (eds.): The Living

Handbook of Narratology. Hamburg: Hamburg University,

2014. http://www.lhn.uni-hamburg.de/article/space [pristupljeno 18. jula 2019.]

Zoran, Gabriel. „Towards a Theory of Space in Narrative”. Poetics

Today, Vol. 5/2, The Construction of Reality in Fiction, (1984): 309-335.

Jasmina Moskovljević Popović

\section{DISCOURSE REPRESENTATION OF URBAN SPACES IN THE SHORT STORY „A DAY IN ROME“ BY IVO ANDRIĆ}

\section{Summary}

The paper examines different types of discourse representation of urban spaces in the short story A Day in Rome by Ivo Andrić. A discourse of narratized description has been identified as the most prominent form of representation of spatiality in the text of this short story, though the discourses of direct reference (naming of cartographic enteties) and description have been present, as well. The absence of discourse representation and characterization of some spaces, or their realization in the highly reduced and impoverished form epitomizes yet another form of discourse representation of spatiality in Andrićs work.

Key Words: urban spaces, types of discourse, narratized description, direct reference (naming), description, absence of discourse; Andrić, short story. 